\title{
ГEPMAHCbKI MOBИ
}

УДК 811.111 '27

DOI https://doi.org/10.32838/2663-6069/2019.2-1/10

Білецька Т. $О$.

Київський національний університет імені Тараса Шевченка

Гаврилюк О. О.

Київський національний університет імені Тараса Шевченка

\section{СЕМАНТИКО-КОГНІТИВНІ МЕХАНІЗМИ РЕПРЕЗЕНТАЦЇ̈ КАТЕГОРІЇ ОЦІНКИ В СУЧАСНОМУ АНГЛОМОВНОМУ ГАЗЕТНО-ЖУРНАЛЬНОМУ ДИСКУРСІ}

\begin{abstract}
У статті проаналізовано семантико-когнітивні механізми і лексичні засоби репрезентації узуальної й оказіональної оцінки в сучасному англомовному газетно-журнальному дискурсі медійної комунікації. Оцінка виявляе риси структурно-семантичної, функціональної, прагмасемантичної категорії. Дослідження зосереджене на вивченні когнітивних передумов, структури, функиії та мовних засобів вираження оцінки. Оцінка як об'єктивно-суб' єктивна категорія відображає иіннісну картину світу представника певної лінгвокультури, який інтерпретує навколишній світ під впливом норм і стереотипів соиіуму. Експлікований або імплікований суб'єкт, об'єкт, оцінна ознака й мотивуюча основа визначають структуру аксіологічного змісту. Очіночність лексичних одиниць у досліджуваному дискурсі детермінована їх лексико-семантичними властивостями і контекстним використанням. У результаті засвідчено, що серед лексичних засобів вираження узуальної й оказіональної очінки в сучасному англомовному газетно-журнальному дискурсі виокремлюються одиниці з нульовою та з позитивною / негативною оиінністю.

Ключові слова: оцінка, ціннісна картина світу, цінність, структура оцінки, раціональна й емоційна оцінка, семантична категорія, конотація / денотація, сигніфікативні / дескриптивні оцінні значення, газетно-журнальний дискурс.
\end{abstract}

Постановка проблеми. Оцінка є однією з найважливіших сторін інтелектуальної діяльності людини і властива процесу відображення дійсності людиною [6, с. 8]. Категорія оцінки належить до базових категорій, за допомогою яких виробляється орієнтація у світі, розуміння явищ, які відбуваються у суспільстві. Через єдність мови й мислення оцінка неодмінно знаходить відображення у мовленні, оскільки суб'єкт наділяє значимістю елементи дійсності, що сприймаються, тож інтерпретуюча функція мови базується на ціннісних параметрах перцепції дійсності [2, с. 6-10; 9]. Аксіологічні фактори відіграють все помітнішу роль у вербалізації думки у різних видах дискурсу, внаслідок чого актуальним видається вивчення мовних засобів репрезентації категорії оцінки в газетно-журнальному дискурсі.
Аналіз останніх досліджень і публікацій. Лексичні засоби вираження оцінки неодноразово були об'єктом наукового аналізу в працях Н. Д. Арутюнової, О. Л. Бессонової, Й. А. Стерніна, В. М. Телії та інших науковців. Базові принципи організації дискурсу були розроблені Т. А. ван Дейком, Р. Ленекером, 3. Гаррісом, В. Чейфом. Серед лінгвістичних розвідок, присвячених газетно-журнальному дискурсу, помітними $\epsilon$ дослідження С. І. Потапенка, Ю. Г. Федорової.

Постановка завдання. Без врахування аксіологічного характеру мислення вивчення комунікації $є$ неповним, оскільки в процесі мовленнєвої діяльності відображення знаходять ціннісні відношення продуцентів повідомлення до предмета мовлення і один до одного $[6$, с. 8]. Тож метою дослідження $є$ виокремлення когнітивних 
передумов, структури, функції й мовних засобів вираження узуальної (інгерентної, внутрішньої) й оказіональної (ситуативної, контекстуальної) оцінки в газетно-журнальному дискурсі.

Виклад основного матеріалу. Газетно-журнальний дискурс як різновид медіа-дискурсу представлений сукупністю текстів і контексту їх створення і грунтується на двох моделях подачі змісту: фактичній - для викладу інформації й авторській, адже факт слугує лише приводом для викладу авторського погляду на подію [3, с. 139]. Газетний дискурс є сприятливим середовищем для виявлення функцій оціночності шляхом простеження його взаємозв'язку з процесом концептуалізації. Поза дискурсом неможливо декодувати оціночність газетних статей. Особливістю газетно-журнального дискурсу $є$ його оцінний характер, оскільки він виконує не лише інформаційну, але й прагматичну функції для передавання інформації із запланованою установкою на іiі соціальну оцінку за допомогою мовних засобів, поєднуючи стандарт і експресію. Більшість сучасних засобів масової інформації використовує імпліцитні механізми формування оцінки для маніпулювання масовою свідомістю [17, с. 115-116].

Оцінка як об'єктивно-суб'єктивна конотація належить ціннісній картині світу адресанта, який сприймає навколишній світ під впливом соціуму [16, с. 187], відображаючи кваліфікативну діяльність свідомості [18, с. 47] і протиставляючи одну етнокультурну спільноту іншій [10, с. 122]. Оцінка свідчить про ступінь пізнаності світу, вона визначається світоглядом носіїв мови, суспільними нормами, стандартами й правилами моралі $[9$, с. 420]. Узуальні норми належать ціннісній картині світу, що базується на побутовому образі світу, який сформувався у свідомості мовного колективу на основі його життєвого досвіду [16, с. 186].

Цінності фіксують позитивне або негативне значення предмета, виявляють себе як складний феномен, що має як суб' єктивні, так і об'єктивні моменти. Зважаючи на це, цінності поділяються на універсальні, групові та індивідуальні. Як концентроване вираження досвіду життєдіяльності соціальної спільноти, цінності складаються в певну систему, якої індивід як член суспільства дотримується в процесі власного оцінювання. Особистісні цінності $€$ індивідуальним відображенням групових або універсальних особливостей сприйняття, що опосередковано соціальною ідентичністю суб'єкта та цінностями референтних для нього контактних груп [11, с. 11]. Науковці зазначають функції цінностей: координуюча (між світом об'єктів і людиною), стимулююча (спрямовує діяльність особи), дидактична й регулююча (прескрептивна) [1, с. 60].

Категорію оцінки слідом за Т. А. Космедою розглядаємо як структурно-семантичну, функціональну, прагмасемантичну, що містить такі поняття, як схвалення/осуд, згода/незгода, симпатія/антипатія. Категорія оцінки - це типове мовне значення з певним денотативно-поняттєвим і конотативним змістом. Основним засобом реалізації у дискурсі семантичної категорії оцінки є конотація, яка визначає належність досліджуваної категорії до сфери прагматики. Конотації базуються на асоціаціях, образних моделях, які у свідомості носіїв мови здійснюють референцію до об' єктів, що вербалізовані лексемою [9]. До структури оиінки входять такі компоненти: експлікований або імплікований суб'єкт; об'єкт - особа чи подія, яким приписуються цінності; оцінна ознака; мотивуюча основа - норми, стереотипи тощо [15, с. 23]. Раціональна й емоиійна оцінки демонструють тісний взаємозв'язок, оскільки оцінка визначає емоції та $є$ їх передумовою $[5$, с. 75 ; 18, с. 31]. Залежно від цих факторів виокремлюють такі семантичні типи оцінки: раціональна, яка міститься в денотаті й грунтується на логічних судженнях про властивості предмета; емоційна, що відображає почуття і ставлення мовця до предмета оцінки; раціонально-емоційна, яка поєднує логічне й образне сприйняття [17, с. 119]. Сдність раціональної й емоційної оцінки призводить до логічного висновку про необхідність розгляду денотації та конотації як двох аспектів лексичного значення, що забезпечуються спільними ментальними механізмами. У контексті таких трактувань раціональна оцінка може володіти не меншим експресивним потенціалом, ніж емоційна оцінка $[7$, c. 64].

Оцінні значення (сигніфікативні) у лексикосемантичних варіантах протиставлені дескриптивним, оскільки останні представляють лише реляцію висловлення 3 навколишнім світом, а оцінні відображають зв'язок між дійсністю і його ментальною моделлю [1; 9].

Оцінка є позитивною або негативною кваліфікацією предмета думки, схвальним або засуджувальним твердженням про те, що активується лінгвістичною одиницею. Оцінка $є$ вираженим у вербальній формі ставленням суб'єкта до предмета, аксіологічні ж ознаки не відображають поняттєву сутність явища, а лише характеризують його в певному аспекті $[8$, с. 125]. 3 огляду на лексичну семантику оцінна сема може бути денота- 
тивним або конотативним компонентом, а також охоплювати обидва аспекти лексичного значення [4, с. 11]. Прескрипції все ж витікають зі змісту поняття і зумовлені його інтерпретацією суспільною свідомістю [14, с. 46]. Сутності можуть оцінюватися як корисні, шкідливі, небезпечні [16, с. 181], правильні / неправиильні, можливі / неможливі, звичайні, доречні, позитивні / негативні [5, с. 84].

У площині синтагматики виокремлюють одиниці не лише 3 позитивною й негативною оцінністю, яка може бути інгерентною й оказіональною, але й з нульовою. Інгерентна оцінність властива слову як одиниці мови, тоді як контекстуальна оцінність виявляється ситуативно в мовленні $[13$, с. 4].

Серед лексичних засобів репрезентації узуальної й оказіональної оцінки в сучасному англомовному газетно-журнальному дискурсі вирізняються одиниці з нульовою та 3 позитивною або негативною оцінністю.

Досліджуючи функціонування аксіологічномаркованих лексичних засобів у газетно-журнальному дискурсі, спостерігаємо нейтралізацію денотативно-сигніфікативного значення, що не закріплено узусом і не відображено в лексикографічних джерелах, проте дає змогу створювати прагматичне навантаження мовних одиниць. У процесі дискурсивної актуалізації слова в структурі його значення може мати місце повна нейтралізація денотативно-сигніфікативного елемента - тоді йдеться про «нульове» денотативносигніфікативне значення або про реалізацію одного із значень (прагматичного, денотативного, сигніфікативного) 3 одночасною нейтралізацією іншого [9]. Лексеми з нульовою оцінністю представлені в англійській мові двома групами:

1. Повністю нейтральні лексичні одиниці 3 інгерентною відсутністю оцінності: "The former White House adviser Steve Bannon has ... predicted that investigations into the president's finances will lead to his political downfall" (The Guardian, May/28/2019).

2. Нейтрально-оцінні номінативні одиниці, у значенні яких оцінність виявляється:

a) у контексті висловлення: "And unlike many news organisations, we have chosen an approach that allows us to keep our journalism accessible to all" (The Guardian, May/29/2019) - попередня фраза 3 контрактивним значенням "unlike many news organisations, we..." створює альтернативний оціночний простір і представляє додаткову ментальну площину для акцентування думки і додає меліоративності ознаки «доступний»; б) в складі словосполучення: "Deutsche Bank employees flagged concerns over possible money laundering through transactions involving legal entities controlled by the president and Kushne" (The Guardian, May/28/2019) - нейтрально-оцінна лексема money містить негативну конотацію через комбінування з одиницею вираження пейоративної оцінки laundering.

Лексеми з позитивною або негативною оцінністю розподіляються в групах:

1. Номінативні одиниці 3 негативно та позитивно оцінними семами, зафіксованими в лексикографічних джерелах:

- прикметники: "Both Pinterest and Zoom made successful debuts on the market this week" (The Telegraph, April/18/2019); "The former White House adviser Steve Bannon has described the Trump Organization as a criminal entity" (The Guardian, May/28/2019);

- дієслова: "The Fawlty Towers actor John Cleese has been criticised for repeating his 2011 claim that London was no longer an English city" (The Guardian, May/29/2019);

- іменники: "Boris Johnson has been summoned to court to face accusations of misconduct in public office over comments made in the run-up to the EU referendum " (The Guardian, May/29/2019).

2. Номінативні одиниці, в яких лексико-семантичні варіанти виявляють позитивну або негативну оцінність залежно від контексту: "Nigel Farage and Vince Cable have divided the country into leavers and remainers" (The Guardian, May/29/2019). Оцінність засудження й схвалення відповідно виділених іменників зумовлена постпозитивною інформацією про соціально-політичні преференції британців, яка виконує роль контексту реалізації прихованих сем оцінності нейтральних одиниць: "to reassure remainers of our intention to stay close to the EU"; на когнітивному рівні здійснюється переструктурування вихідного оціночного ментального простору реципієнта [12, с. 14].

Висновки і пропозиції. Оцінка є структурносемантичною, функціональною, прагмасемантичною категорією, тому оціночність мовної одиниці у досліджуваному матеріалі зумовлена їі лексико-семантичними властивостями і контекстним вживанням. Лексичні одиниці вираження узуальної (інгерентної) та оказіональної (контекстуальної) оцінки відображають стереотипи англомовної свідомості, відбиваючи світогляд, знання та уявлення суб' єктів газетно-журнального дискурсу в сучасному медійному просторі. Оцінка як об'єктивно-суб' єктивна категорія 
відображає ціннісну картину світу представника певної лінгвокультури. Ситуативна оцінка відображає комбінації взаємодії ментальних просторів у свідомості читача: введення додаткової когнітивної площини для контрастування оцінюваної властивості та переструктурування мисленнєвого простору для акцентування імпліцитної оцінки. У перспективі дослідження планується виявити мовні засоби реалізації аксіологічно маркованих концептів у досліджуваному дискурсі, якими оперують журналісти для здійснення впливу на адресата.

\section{Список літератури:}

1. Арутюнова Н. Д. Типы языковых значений. Оценка. Событие. Факт. Москва : Наука, 1988. 341 с.

2. Баранов А. Н., Добровольский Д. О. Постулаты когнитивной семантики. Известия РАН. Серия литературы и языка. 1997. Т. 56. № 1. С. 11-21.

3. Бацевич Ф. С. Основи комунікативної лінгвістики. Київ : Академія, 2004. 342 с.

4. Бессонова О. Л. Оцінка як семантичний компонент лексичного значення слова : автореф. дис. ...канд. філол. наук : 10.02.19. Донецьк, 1995. 18 с.

5. Гамзюк М. В. Емотивний компонент значення у процесі створення фразеологічних одиниць: на матеріалі німецької мови. Київ : Вид. центр КДЛУ, 2000. 256 с.

6. Гилева А. В. Оценочные стратегии в языке британской качественной и массовой прессы: автореф. дисс. ... канд. филол. наук : 10.02.04. Москва, 2005. 26 с.

7. Голубовская И. А. Этнические особенности языковых картин мира. Киев : Издательскополиграфичный центр «Киевский университет», 2002. 293 с.

8. Иванченко М. Ю. Номинация «поврежденности» в английском языке. Номинащия и дискурс. Минск : МГЛУ, 2006. С. 125-126.

9. Космеда Т. А. Аксиологическая прагмалингвистика к вопросу о статусе категории оценки и этапах становления в украинской лингвофилософии. Слово. Фраза. Текст. Москва : Азбуковник, 2002. C. 414-422.

10. Пищальникова В. А. Концепт как инструмент диагностики этнической напряженности. Языковое сознание: теоретические и прикладные аспекты. Москва; Барнаул : Изд-во Алт. ун-та, 2004. С. 121-128.

11. Приходько Г. І. Способи вираження оцінки в сучасній англійській мові. Запоріжжя : ЗДУ, 2001. $362 \mathrm{c}$.

12. Руденко А. В. Модификация оценки в дискурсе СМИ (когнитивно-прагматический аспект) : автореф. дисс. ... канд. филол. наук : 10.02.19. Москва, 2012. 27 с.

13. Соловйова Л. Ф. Вираження аксіологічних категорій у сучасній англійській мові (атрибути, предикативи і релятиви оцінки) : автореф. дис. ... канд. філол. наук : 10.02.04. Харків, 2000. 19 с.

14. Стернин И. А. О понятии коммуникативного сознания и некоторых особенностях русского коммуникативного сознания. Языковое сознание: теоретические и прикладные аспекты. Москва; Барнаул : Изд-во Алт. ун-та, 2004. С. 36-63.

15. Телия В. Н. Коннотативный аспект семантики номинативных единиц. Москва, 1986. 143 с.

16. Телия В. Н. Русская фразеология. Семантический, прагматический и лингвокультурологический аспекты. Москва : Языки русской культуры, 1996. 284 с.

17. Федорова Л. М. Категорія оцінки: до проблеми становлення та вираження в слові (на матеріалі метафор газетно-журнальної періодики). Украӥнська мова. 2013. № 1. С. 115-121.

18. Школяренко В. І. Динаміка розвитку фразеологічної системи німецької мови XIX - XX століття. Суми : СумДПУ ім. А. С. Макаренка, 2003. 324 с.

\section{СЕМАНТИКО-КОГНИТИВНЫЕ МЕХАНИЗМЫ РЕПРЕЗЕНТАЦИИ КАТЕГОРИИ ОЦЕНКИ В СОВРЕМЕННОМ АНГЛОЯЗЫЧНОМ ГАЗЕТНО-ЖУРНАЛЬНОМ ДИСКУРСЕ}

В статье проанализированы семантико-когнитивные механизмы и лексические средства репрезентации узуальной и окказиональной оценки в современном англоязычном газетно-журнальном дискурсе медийной коммуникации. Оченка является структурно-семантической, функциональной, прагмасемантической категорией. Исследование сосредоточено на изучении когнитивных предпосылок, структуры, функиии и языковых средств выражения оценки. Оиенка как объективно-субъективная категория отражает иенностную картину мира представителя определенной лингвокультуры, который интерпретирует окружающий мир под влиянием норм и стереотипов социума. Эксплицированный или имплицитный субъект, объект, оценочный признак и мотивирующая основа определяют структуру аксиологического содержания. Оченочность лексических единии в исследуемом дискурсе детерминирована их лексико-семантическими свойствами и контекстным использованием. В результате выделены 
лексические средства выражения узуальной и окказиональной оиенки в современном англоязычном газетно-журнальном дискурсе с нулевой и положительной / отрицательной оценочностью.

Ключевые слова: оченка, иенностная картина мира, ценность, структура оценки, узуальная и окказиональная оценка, семантическая категория, коннотаџия / денотаџия, сигнификативные / дескриптивные оценочные значения, газетно-журнальный дискурс.

\section{SEMANTIC AND COGNITIVE MECHANISMS OF REPRESENTING EVALUATION CATEGORY IN MODERN ENGLISH NEWSPAPER DISCOURSE}

The article analyzes semantic and cognitive mechanisms and lexical means of representing fixed and occasional evaluation in modern English newspaper discourse of media communication. The research focuses on the study of cognitive background, structure, functions, and linguistic means of its expression. Evaluation appears to be structurally semantic, functional and pragmatic semantic category. The evaluation as an objective and subjective category reflects the value world image of the representatives of a certain linguistic culture, thus interpreting the world under the influence of the norms and stereotypes of the society. An explicit or implicit subject, object, estimated feature and motivating factor determine the structure of the axiological content. The value of lexical units in the discourse under analysis is determined by their lexical-semantic variants and contextual usage. As a result, there were distinguished the lexical units of expressing the fixed and occasional zero and positive / negative evaluation in the contemporary English newspaper discourse.

Key words: evaluation, value picture of the world, value, structure of evaluation, fixed and occasional evaluation, semantic category, connotation / denotation, syntactic / descriptive evaluative values, newspaper discourse. 